\title{
Evaluation of Heavy Metals Concentration and Its Consumption Risk in Trout Fish (Oncorhynchus Mykiss)
}

\author{
Hadi Tahsini ${ }^{*}$, Maryam Alizadeh ${ }^{2}$, Hoshyar gavilian $^{3}$ \\ 1. M.Sc. Student, Environment Pollution, Faculty of Natural Resources, \\ University of Kurdistan, Sanandaj, Iran \\ 2. M.Sc. Student, Environment Pollution, Faculty of Natural Resources and Earth Sciences, \\ University of Kashan, Iran \\ 3. M.S Student in Natural Resources Engineering Department of Environment, \\ University of Kurdistan, Iran \\ *E-mail: haditahsini@yahoo.com \\ Received: 22 Feb 2018 ; Accepted: 21 Jul 2018
}

\begin{abstract}
Background and Objectives: Nowadays, the pollution of aquatic ecosystems caused by entry of heavy metals is an issue that makes it essential to check the wholesome of the aquatic animals that are consumed by human. When these metals enter the canvas of aquatic organisms, cause tension due to bioavailability, and their toxicity leads to teratogenic, mutagenic and carcinogenic effects in living organisms

Methods: Thirty rainbow trout were prepared from each fishing farm pond which are located in Sanandaj (Nanale Village) and Kamyaran (Diwaznaw Village). Then, samples were prepared using acid digestion method in the laboratory and the concentration of these metals was measured using atomic absorption spectrometer (Phonix 986). The achieved data were analyzed using SPSS software.

Results: The average concentration of the Copper in liver and muscle tissues was 1.53 and 0.15 , Magnesium 3.7 and 7.57, Iron 0.28 and 0.6, Zinc 4.52 and 1.05, and Nickel 0.04 and $0.03 \mu \mathrm{g} / \mathrm{g}$ of fresh weight. The maximum daily consumption allowance was $888.7 \mathrm{~g}$ for adults and $177.77 \mathrm{~g}$ for children.

Conclusion: The average concentration of Copper, Iron, Zinc, Nickel and Magnesium in muscle tissue of rainbow trout compared to international standards, is slightly lower than that at current consumption rates, long-term health risks to consumers is realized.
\end{abstract}

Keywords: Heavy metals, Rainbow trout (Oncorbynchus mykiss), length, Fish farming ponds, Risk assessment, Consumption. 


\title{
ارزيابى غلظت فلزات سنكين و ريسك مصرف آن در ماهى قزلآلاى رنتين كمان (Oncorhynchus mykiss) در حوضجههاى يرورش ماهى (مطالعه موردى: شهرستان كامياران و سنندج)
}

\author{
هادى تحسينى"'، مريم عليزاده'، هوشيار كويليان" \\ ' دانش آموخته كارشناسى ارشد، آلودگى محيط زيست، دانشكده منابع طبيعى، دانشگاه كردستان، سنداج، ايران

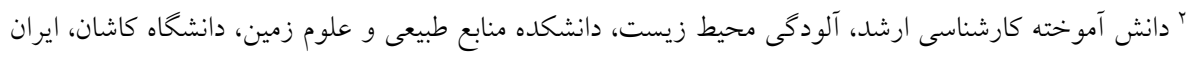

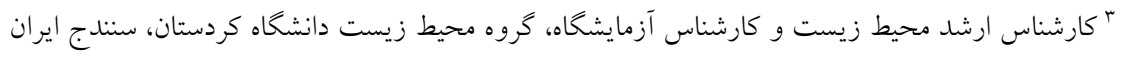

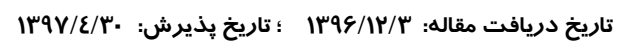

\section{קكيد}

زمينه و هدف: امروزه آلودكى اكوسيستمهاى آبى در اثر ورود فلزات سنكين، امرى است كـه بردسى ســامت آبزيسان

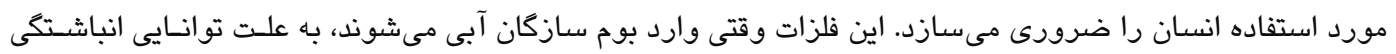

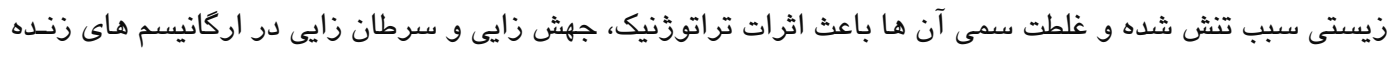

مى شود.

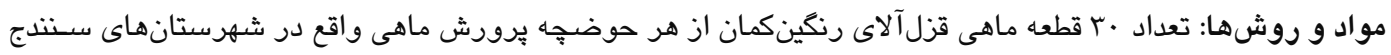

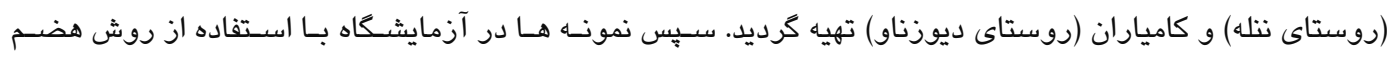

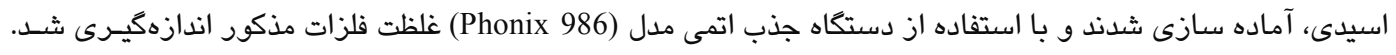

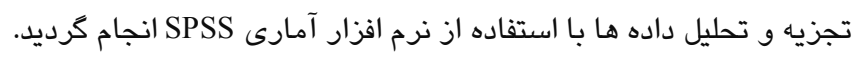

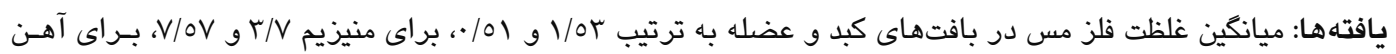

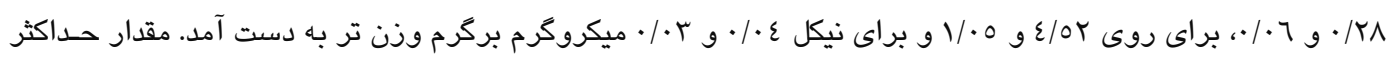

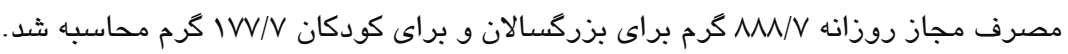

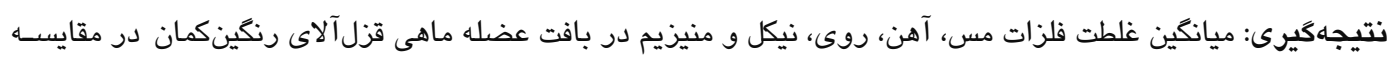

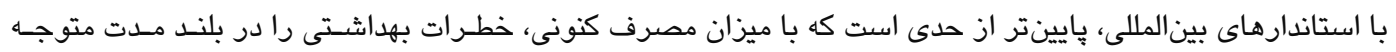
مصرف كتندان آن كند.

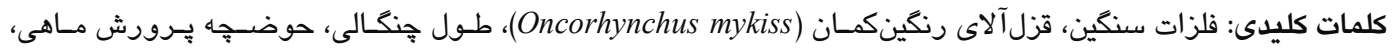

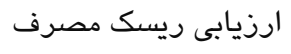


ارزيابى غلظت فلزات سنكين و ريسك مصرف آن در ماهى قزلآلاى رنكينكمان (Oncorhynchus mykiss) در حوضجههاى بِرورش ماهى

اصلى تغيير شكل زيستى فلزات اسـت. ايسن انـدام عمــتاً در معرض فلزات سنخين قرار دارد و اين مواد از طريـق دستخـاه

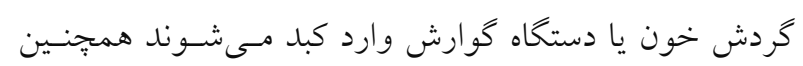

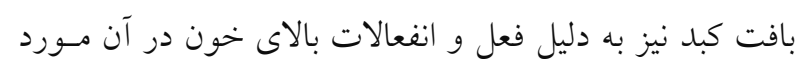

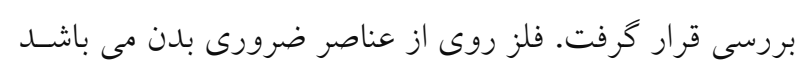

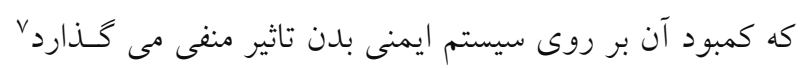

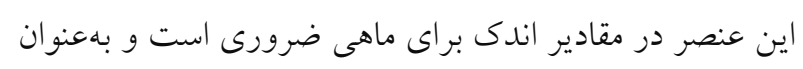

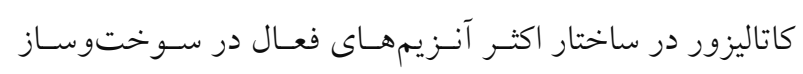

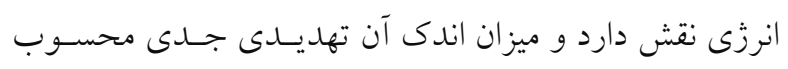

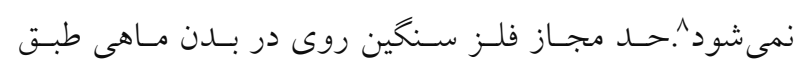

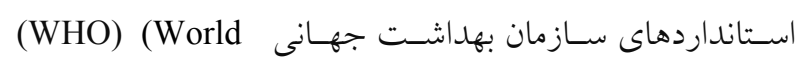
(Health Organization) (Food and Agriculture Organization) (FAO)

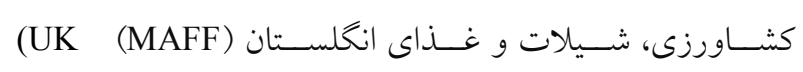
Ministry of Agriculture Fisheries and Food)

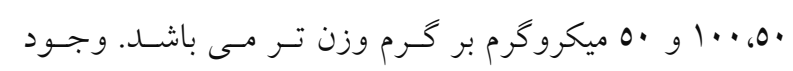

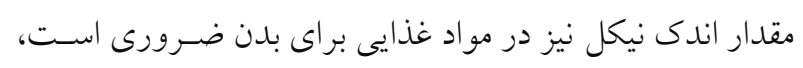

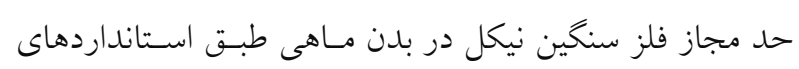

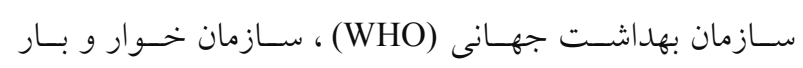

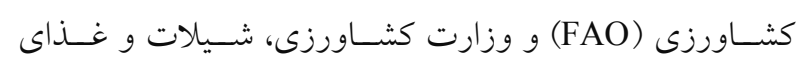

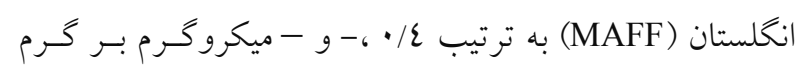

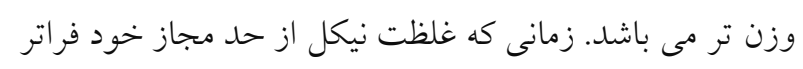

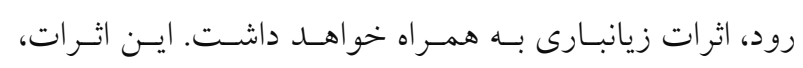

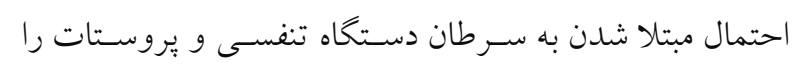

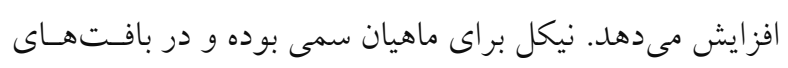

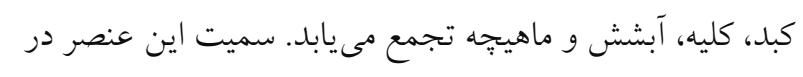

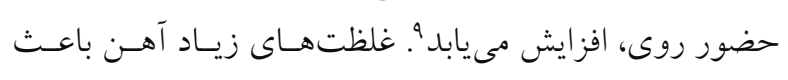

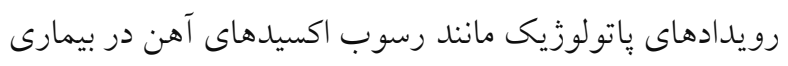

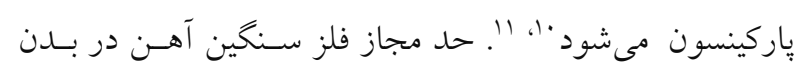

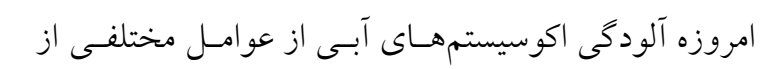

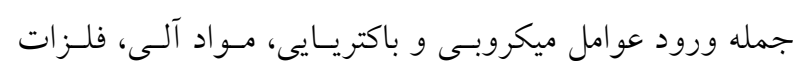

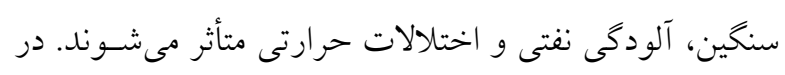

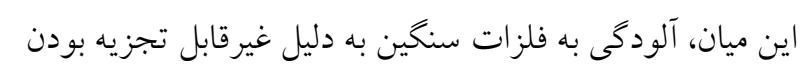

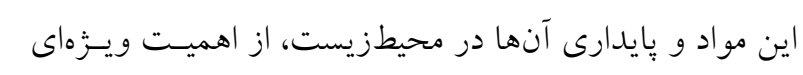

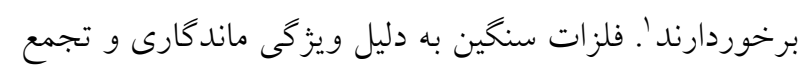

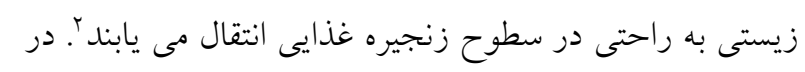

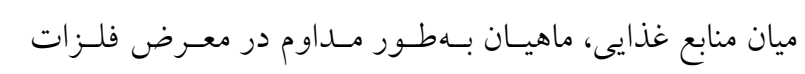

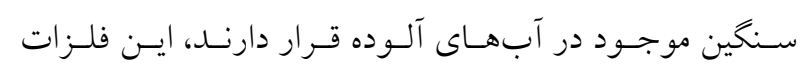

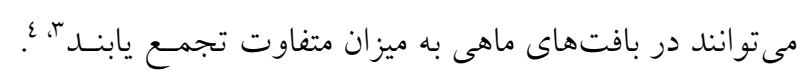

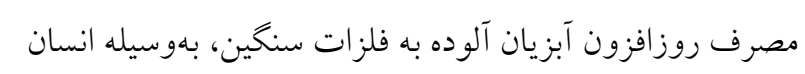
و مسموميتهاى ناشى از آنها در .0 سـال كذشـته آشـكارتر

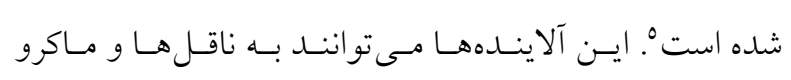

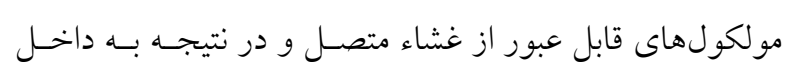

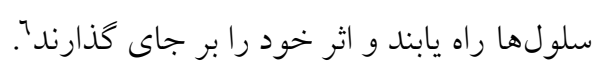

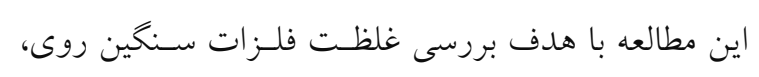

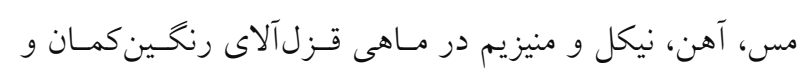

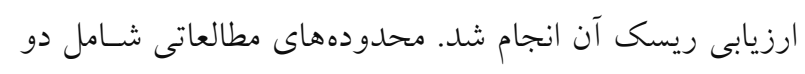

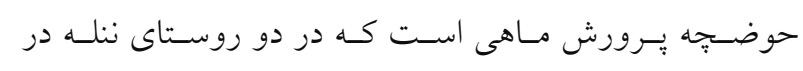

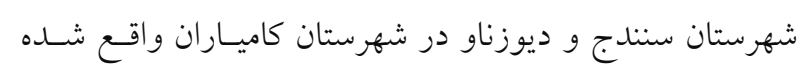

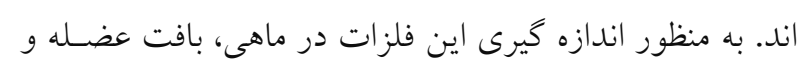

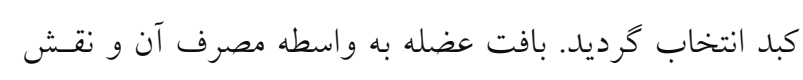

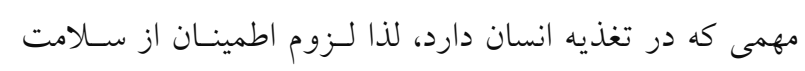

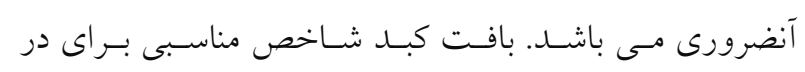

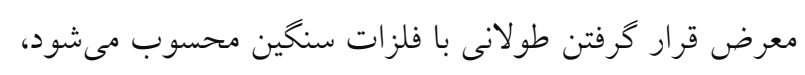

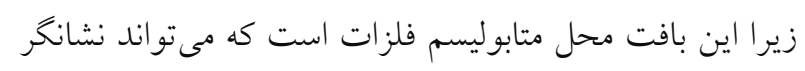

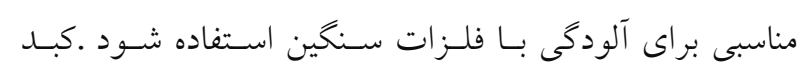

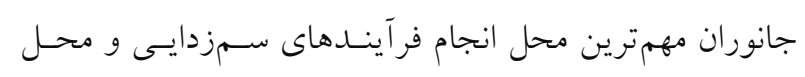


" " . تصميم كيرىهاى مديريتى زيستمحيطى بر اساس ارزيابى

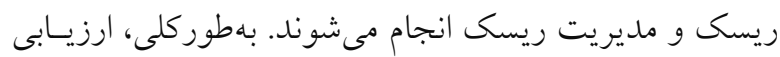

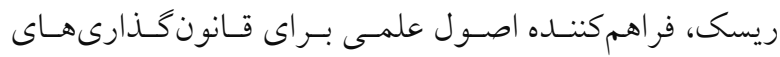

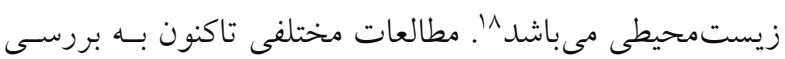

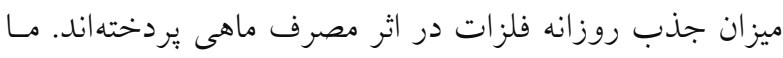

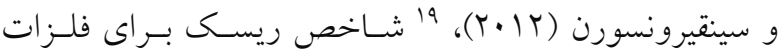
مس، روى، سرب و كادميوم را بيش از يك محاسـبه نمودنـــ.

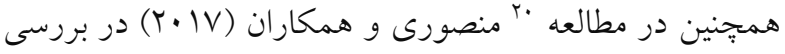

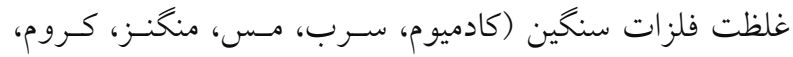

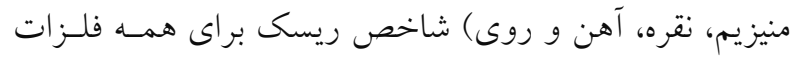

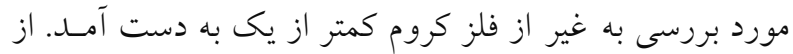

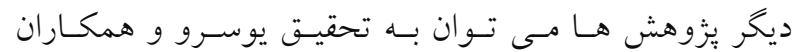

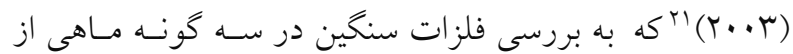
جمله كفال طلايسى در سـواحل جنـوبى آتلانتيـى در اسـيانيا،

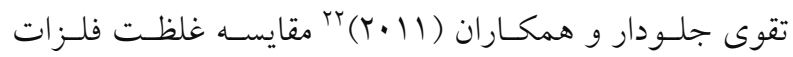

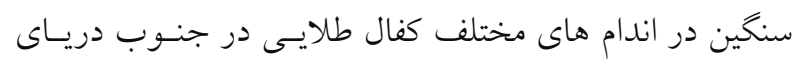

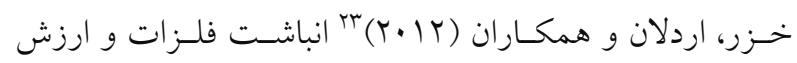

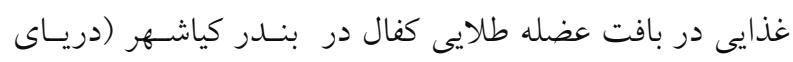
خزر) اشاره نمود.

\section{مواد و روشها منطقه مورد مطالعه}

محدوده هاى مطالعاتى شامل دو حوضجه پِرورش مـاهى

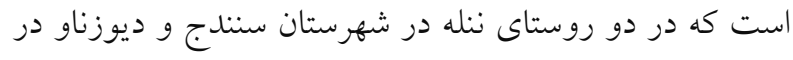

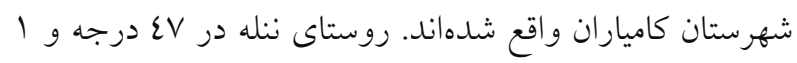

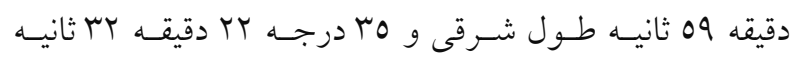

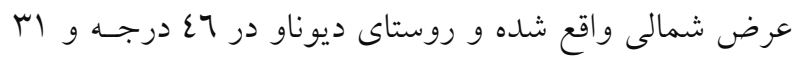

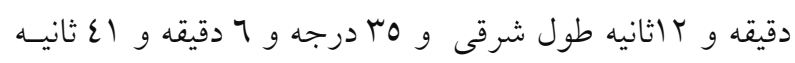

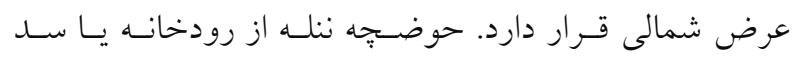
قشلاق سنتلج و حوضجه ديوزنا و از رودخانه سيروان تـأمين

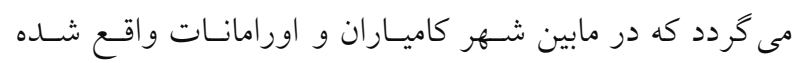

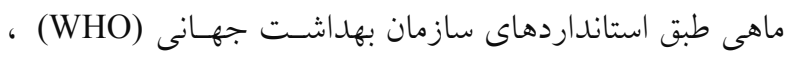

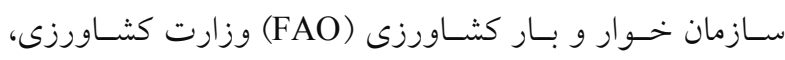

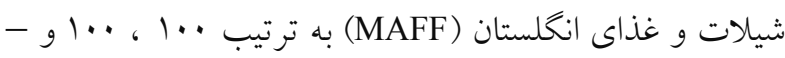

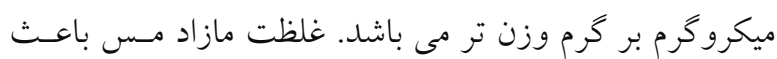

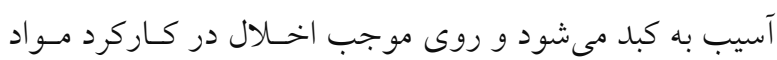

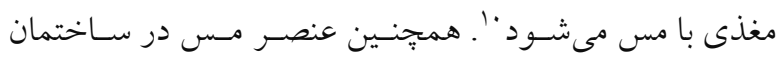

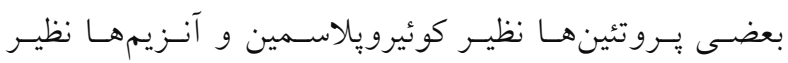

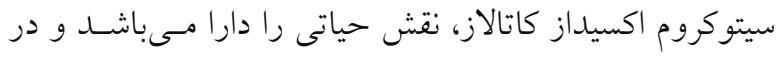

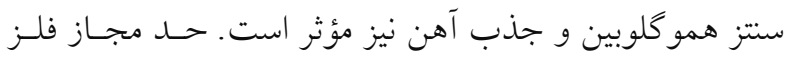
سنخين مس در بدن ماهى طبق استانداردهاى سازمان بهداشت جهانى (WHO) ، سـازمان خـوار و بـار كشـاورزى (FAO) و

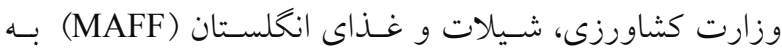

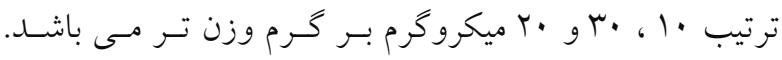

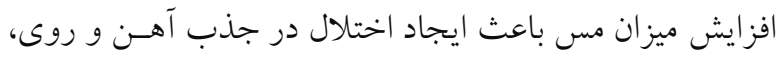

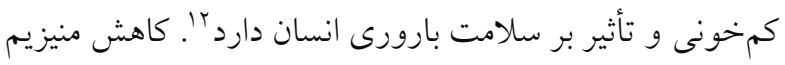

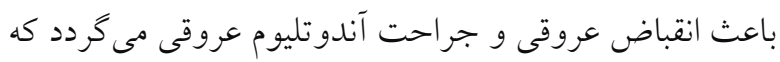

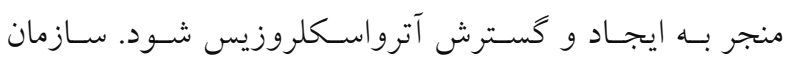

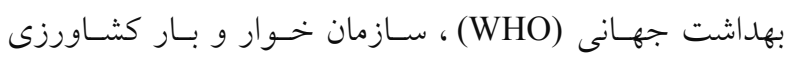

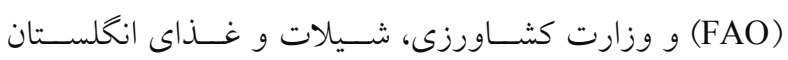
هيج حد مجازى را براى فلز سنخين منيـزيم تعيـين وزين (MAFF)

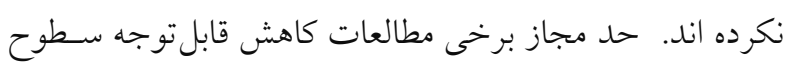
سرمى منيزيم را در بيماران مبتلا به بيمارىهاى عروقى نشـان لتهان دادهاند سا، عا، 10. ارزيابى ريسك غذايى فلزات سنخين را مى توان بـهوسـيله

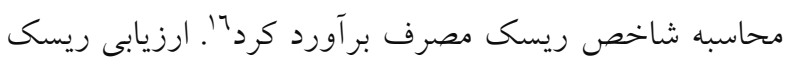

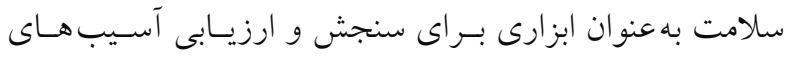

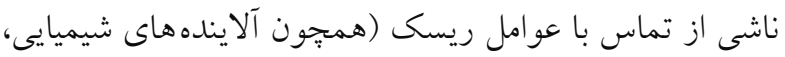

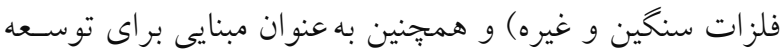

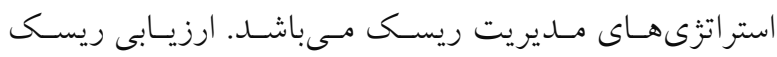

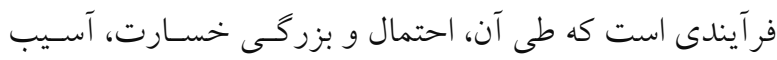
ناشى از يك ريسك و تهديد بالقوه سلامتى تخمين زده مى شود 
ارزيابى غلظت فلزات سنكين و ريسك مصرف آن در ماهى قزلآلاى رنكينكمان (Oncorhynchus mykiss) در حوضجههاى برورش ماهى

تزريق و غلظت فلزات مـوردنظر بـه روش شـعله بـر حسـب ميلى گرم بر گرم وزن تر اندازه گيرى شدند و محلول استاندارد

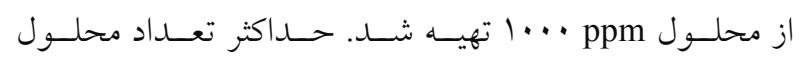
استاندارد 0 محلول است كه حاوى غلظـتهـاى مشخصى از فلـزات مــوردنظر اسـت كـهـ در ايــن آزمـايش از بمحلــول استاندارد استفاده شد. بعد از كاليبره كردن دسـتخاه بـا محلـول

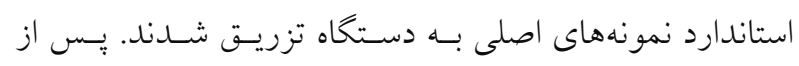
ميانخين گيرى فلزات توسط اتمهـاى عنصـر مـوردنظر بـس از تزريق نمونه به داخل كوره توسط دستخاه داده شـد. سـبس از روش منحنى درجهبنـدى طبـق ترتيـب اسـتانداردها و قرائست ميزان جذب آنها كاليبراسيون انجام شد. تجزيهوتحليل آمارى

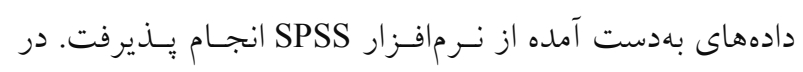

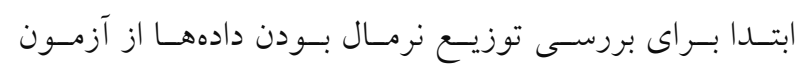

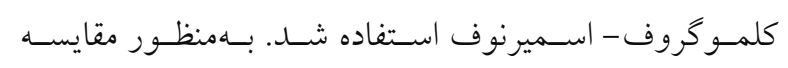
غلظتهاى هر فلز در بافتهاى كبد و عضله از آزمونتى تسـت

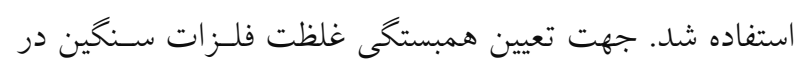

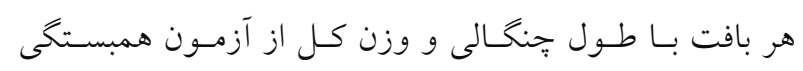
بيرسون استفاده شد. جهـت محاسـبه شـاخص ريسـى (HQ)

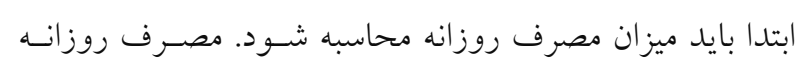

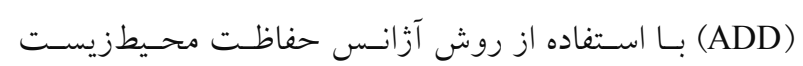

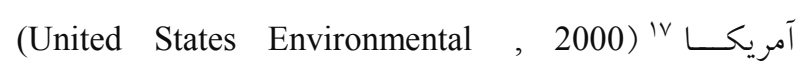
Protection Agency $\mathrm{ADD}=\mathrm{Cm} * \mathrm{DC} / \mathrm{BW}$

رابطه (1)

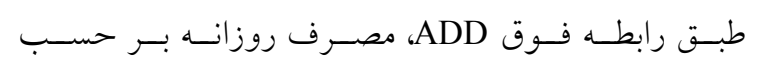

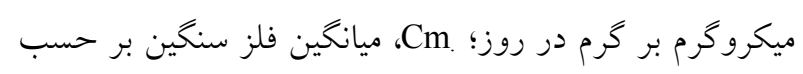

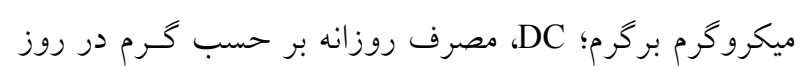

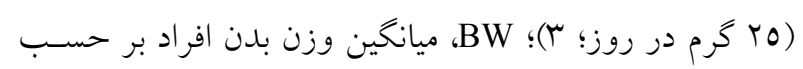

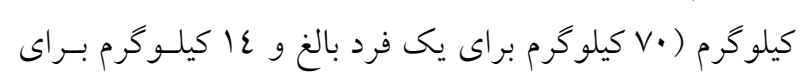
كود كان) مىباشد.

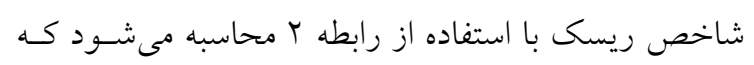
طبق آن اخر بيش از يك باشد ريسك مصـرف وجـود دارد و
است. در اين يزوهش از حوضجهه هاى مستطيل شكل اسـتفاده

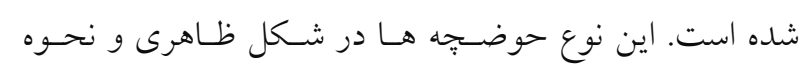
ورود و خروج آب شبيه كانال هاى دراز بتسونى هسـتند ابعـاد

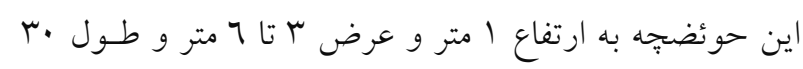
تا •ع متر مى باشد.

\section{روش تحقيق}

تعداد •7 قطعه ماهى قزل آلاى رنخين كمان در تابستان سال

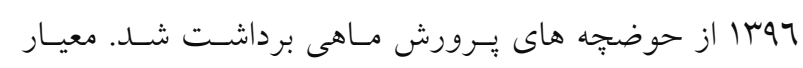

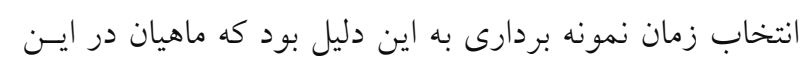

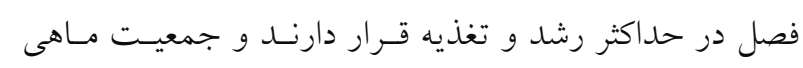
قزل الاى رنخين كمان در اين فصل حداكثر مى باشد. انتخـاب

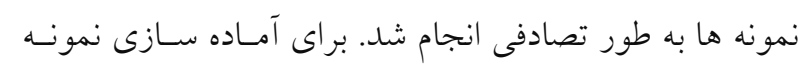

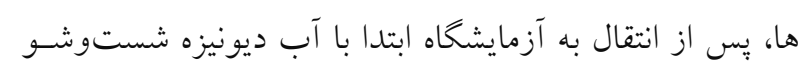

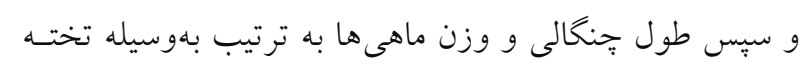

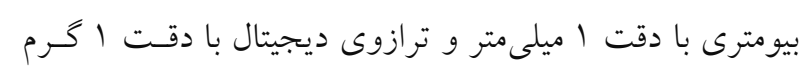

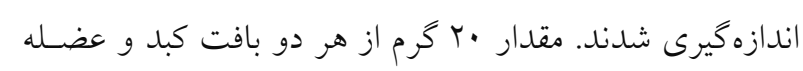

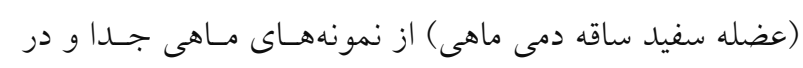

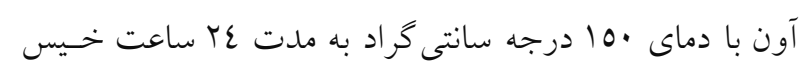
كرديد. سبس نمونه هاى خيس شده به دستخاه دسيكاتور انتقال

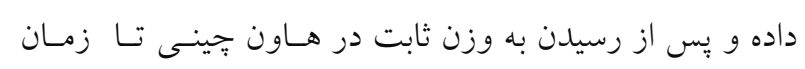

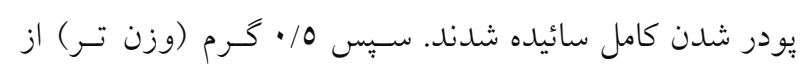

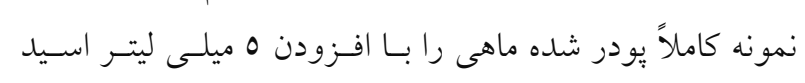

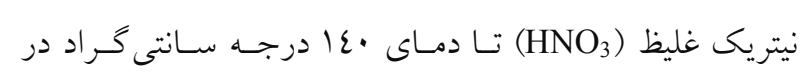
حمام التراسونيك حرارت داده شدند تا محلولى كـاملاً شـفاف

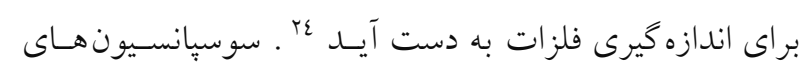

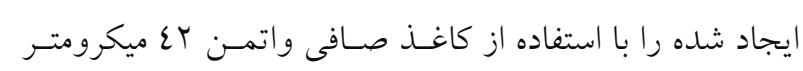
صاف و محلول صاف شده را به يك بالن مـدرج منتقـل و بـهـ

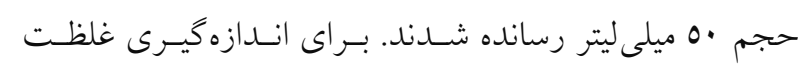

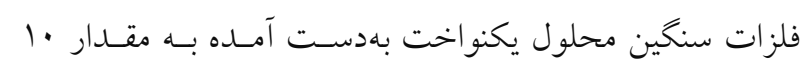

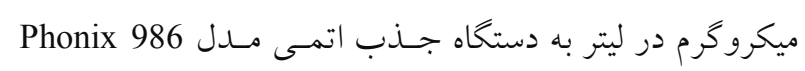




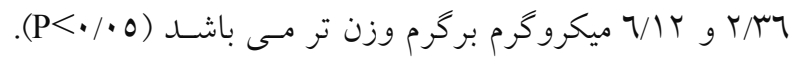

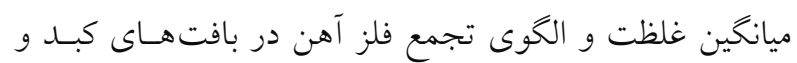

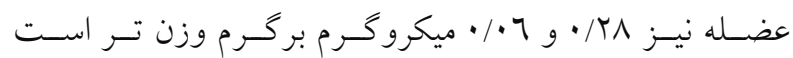

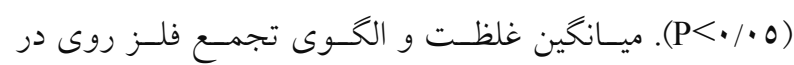

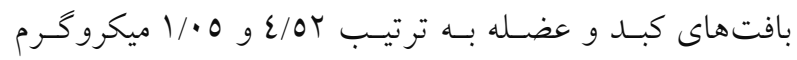

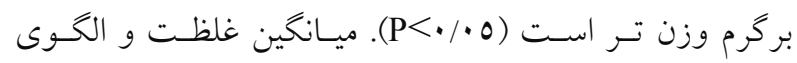

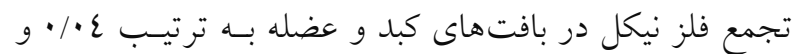

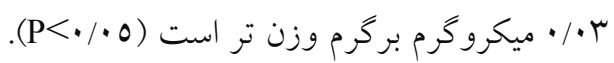

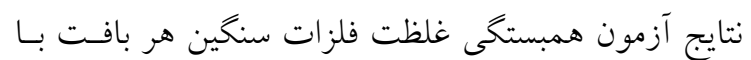

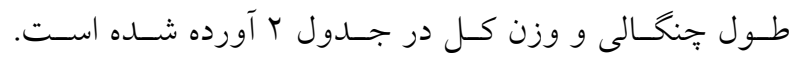

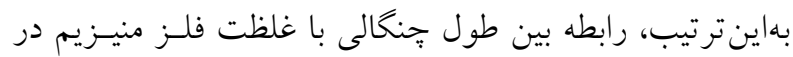
هر دو بافت كبد و عضله همبستئى معنسى دارى وجـود دارد.

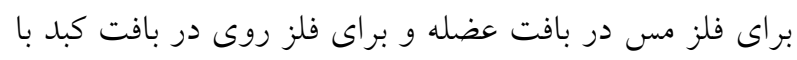

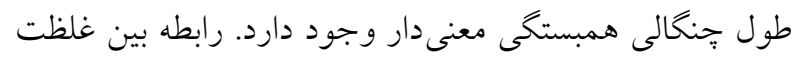

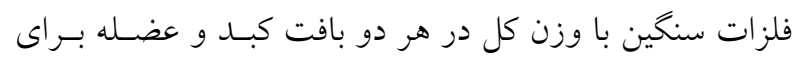

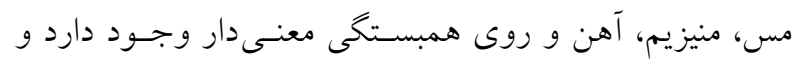

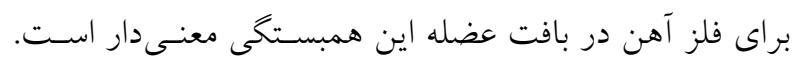

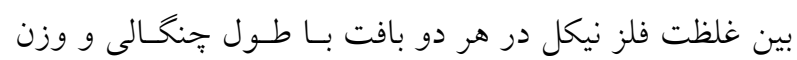
كل رابطه معنى دارى وجود نداشت.
اكر كمتر از يك باشد، ريسك وجود ندارد.

$$
\mathrm{HQ}=\mathrm{ADD} / \mathrm{RFD}
$$

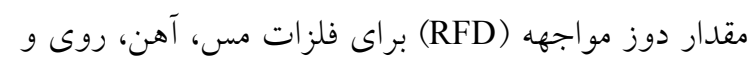

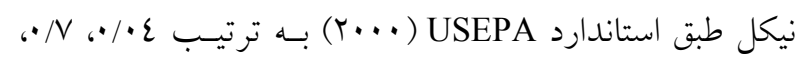

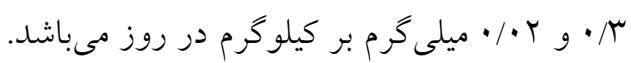

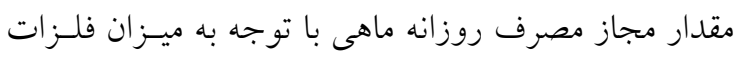
مذكور در مطالعه حاضر از رابطه ب محاسبه مىشود. $\mathrm{CR}=(\mathrm{RFD} * \mathrm{BW}) / \mathrm{C}$ رابطه (r) (ب) (ب) طبق رابطه فوق CR، حداكثر ميزان مجـاز مصـرف در روز بر حسب كرم در روز؛ C، ميانخين غلظت فلز موردمطالعـه بــــ حسب ميكروگرم بر گرم مىباشد.

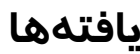

مشخصات آمارى غلظت فلزات سنخين در بافت عضـله و كبد ماهى قزل آلاى رنخين كمان در جدول الذكر شــه اسـت.

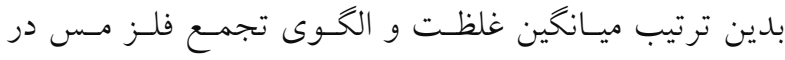

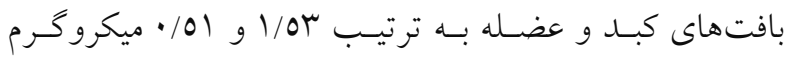

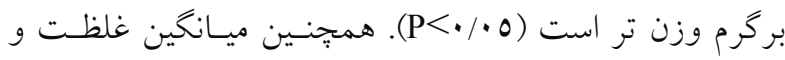

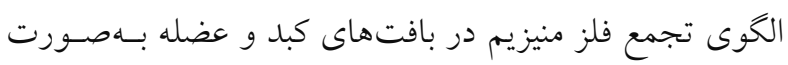

جدول ا: مشخصات آمارى غلظت فلزات سنخين در بافت عضله و كبد ماهى قزل آلاى رنخين كمان (ميكروخرم بركرم وزن تر)

\begin{tabular}{|c|c|c|c|c|c|}
\hline انحر اف معيار & ميانگين & حداقل & حدا كثر & بافت & فلز \\
\hline $1 / 1$ & 1/ora & $\cdot / \varepsilon$ & $\varepsilon / 91$ & كبد & \multirow[b]{2}{*}{ مس } \\
\hline 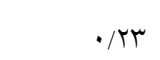 & $\cdot 101^{b}$ & .110 & $\cdot / 91$ & عضله & \\
\hline Y/AV & $r / v^{a}$ & $\cdot /$ ro & $9 / 9 \varepsilon$ & كبد & \multirow[b]{2}{*}{ منيزيم } \\
\hline$r / 91$ & $\mathrm{~V} / \mathrm{OV}^{\mathrm{b}}$ & $\varepsilon / \cdot r$ & $1 \pi / 90$ & عضله & \\
\hline$\cdot / \cdot \wedge$ & $\cdot / r \Lambda^{\mathrm{a}}$ &.$/ r$ & $\cdot / \Sigma \Lambda$ & كبد & \multirow{2}{*}{ آهن } \\
\hline$\cdot / 1$ & $\cdot / \cdot 7^{b}$ & $\cdot / \cdot r$ &.$/ 70$ & عضله & \\
\hline $1 / 7$ & $\varepsilon / 0 r^{a}$ & T/T & $\Lambda / 9 V$ & كبد & \multirow[b]{2}{*}{ روى } \\
\hline$\cdot / \varepsilon \varepsilon$ & $1 / .0^{b}$ & $\cdot /$ To & $1 / 91$ & عضله & \\
\hline$\cdot / 17$ & $\cdot / \cdot \varepsilon^{\mathrm{a}}$ &.$/ \cdot r$ & $\cdot / \cdot V$ & كبد & \multirow{2}{*}{ نيكل } \\
\hline.$/ \cdot 1$ &.$/ . r^{\mathrm{b}}$ &.$/ \cdot 1$ &.$/ \cdot 7$ & عضله & \\
\hline
\end{tabular}


ارزيابى غلظت فلزات سنكين و ريسك مصرف آن در ماهى قزلآلاى رنكينكمان (Oncorhynchus mykiss) در حوضجههاى بِرورش ماهى

حروف متفاوت در ستون مربوط به هر فلز نشانه تفاوت معنىدارى در سطح ه• • است.

جدول ץ: نتايج تحليل همبستخى بيرسون بين غلظت فلزات سنگين هر بافت با طول جنگكالى (ميلىمتر) و وزن كل (كرم)

\begin{tabular}{|c|c|c|c|c|c|}
\hline \multicolumn{2}{|c|}{ وزن كل } & \multicolumn{2}{|c|}{ طول جن:خالى } & \multirow[t]{2}{*}{ بافت } & \multirow[t]{2}{*}{ فلز } \\
\hline P_Value & $\mathbf{r}$ & P_Value & $\mathbf{r}$ & & \\
\hline . & $\cdot / 01 r^{* * *}$ &.$/ 1 T$ & $\cdot / T \cdot r$ & كبد & \multirow[b]{2}{*}{ مس } \\
\hline$\cdot$ & $\cdot /\left.04\right|^{* * * 3}$ &.$\cdots 1$ & 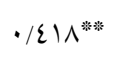 & عضله & \\
\hline . & $\cdot / 0 V \varepsilon^{* * m^{*}}$ &.$/ \cdot 1$ & 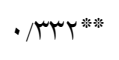 & كبد & \multirow[b]{2}{*}{ منيزيم } \\
\hline . & $\cdot / 09 V^{* * *}$ &.$/ \cdot 7$ & $\cdot /$ ro. & عضله & \\
\hline$\cdot / \mathrm{VVI}$ & $\cdot / \cdot r \Lambda$ & $\cdot / 479$ &.$/ 11 \wedge$ & كبد & \multirow{2}{*}{ آهن } \\
\hline.$/ \cdot 1 \varepsilon$ & $\cdot \mu \mid \varepsilon *$ & $\cdot / 290$ &.$/ \cdot 9$ & عضله & \\
\hline . & $\cdot 101 r^{* * * *}$ & $\cdot / \cdot \varepsilon r$ & • & كبد & \multirow[b]{2}{*}{ روى } \\
\hline$\% v V$ & $\cdot \mu \varepsilon V^{* * * *}$ & $\cdot|\Lambda|$ & $-\cdot / \cdot r T$ & عضله & \\
\hline.$/ .97$ & $\cdot / T I V$ & $\cdot / \wedge \varepsilon \varepsilon$ & $-\cdot / \cdot Y 7$ & كبد & \multirow{2}{*}{ نيكل } \\
\hline זחת/. &.$/ T V$ & $\cdot / \wedge \varepsilon Y$ & $\cdot / \cdot r 7$ & عضله & \\
\hline
\end{tabular}

جدول سا: نتايج تحليل همبستخى ييرسون بين غلظت فلزات سنخين (ميكروخرم بركرم وزن تر)

\begin{tabular}{|c|c|c|c|c|c|}
\hline نيكل & روى & آهن & منيزيم & مس & \\
\hline & & & & 1 & مس \\
\hline & & & 1 & $\cdot 100 \Lambda^{* * *}$ & منيزيم \\
\hline & & 1 & $\cdot / \cdot \wedge \Lambda$ & $-\cdot r \varepsilon r$ & آهن \\
\hline & 1 & - - ror & $\cdot / \varepsilon\urcorner \varepsilon^{* * * *}$ & $\cdot / V \cdot 0^{* * * *}$ & روى \\
\hline 1 & $\cdot /|\varepsilon|$ & $-\cdot / \cdot \varepsilon \varepsilon$ &.$/ 10 \varepsilon$ &.$/ 1 T \varepsilon$ & نيكل \\
\hline
\end{tabular}

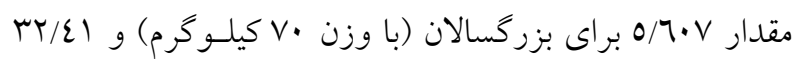
براى كودكان (با وزن عا كيلوگرم)، بيانگر اين مطلب است كه

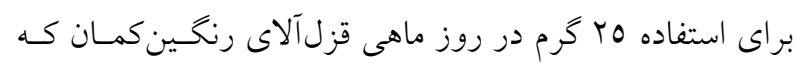
به عنوان ميـانخين مصـرفى تعيسين شــده توسـط سـالنامه آمـار

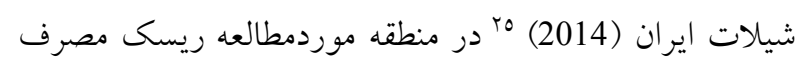
وجود دارد. طبق نتايج مقـدار حسـاكثر مصـرف مجــاز روزانـه

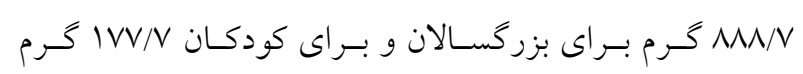

در جدول ب نتايج آزمون همبستخى بيرسـون بـين غلظـت

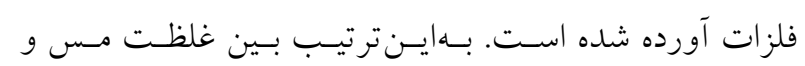
منيـزيم، مسس و روى، منيـزيم و روى همبسـتخى معنسى دارى

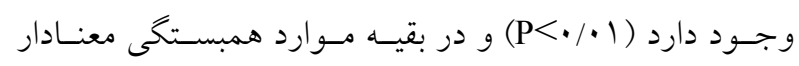
وجود ندارد.

با توجه بـه نتـايج مربسوط بـه محاسبه مجمـوع شـاخص

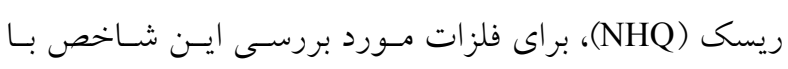


جدول ع: مقادير شاخص ريسك و حداكثر ميزان مجاز مصرف مجاز روزانه عضله ماهى قزلآلاى رنخين كمان

\begin{tabular}{|c|c|c|c|c|c|}
\hline شاخص ريسك & حداكثر مصرف مجاز روزانه & حسرف روزانه (ADD) بر & مضانگين غلظت فلز در & فلز & رده سنى \\
\hline$\varepsilon / 0 \vee 0$ & $0 / 0$ & $\cdot / \cdot r$ & $\cdot / 01$ & مس & \\
\hline . & $117 / 7$ &.$/ \cdot T$ &.$/ .7$ & آهن & بزرگسالان \\
\hline $1 / T_{0}$ & $r \cdot$ & $\cdot$ rvo & $1 / .0$ & روى & (·كيلوكرمى) \\
\hline 1 & $\varepsilon \tau /\rceil$ & $\cdot / \cdot r$ & $\cdot / \cdot r$ & نيكل & \\
\hline $0 / 7 \cdot V$ & $M M N / V$ & $\cdot / \varepsilon r V$ & $1 / 70$ & جمع & \\
\hline r & $1 / 1$ & $\cdot / \cdot 7$ & $\cdot 101$ & مس & \\
\hline.$/ 17$ & $17 \pi / r$ &.$/ 11$ &.$/ \cdot 7$ & آهن & كودكان \\
\hline T/YO & $\varepsilon$ & l/AVO & $1 / .0$ & روى & (عا كيلو گرمى) \\
\hline$r$ & $9 / r$ &.$/ .7$ & $\cdot / \cdot r$ & نيكل & \\
\hline$r T / \varepsilon l$ & $\mathrm{IVV} / \mathrm{V}$ & $T / 1 \cdot 0$ & $1 / 70$ & جمع & \\
\hline
\end{tabular}

جدول ه: مقايسه ميزان غلظت فلزات سنخين در تحقيق حاضر با حد مجاز استانداردهاى بينالمللى (ميكروخرم بر گرم وزن تر)

\begin{tabular}{|c|c|c|c|c|c|c|}
\hline منابع & نيكل & روى & آهن & منيزيم & مس & استانداردها \\
\hline WHO, $1996^{26}$ & $\cdot / \varepsilon$ & $1 \cdots$ & $1 \cdots$ & - & 1. & WHO \\
\hline FAO, $2000^{27}$ & - & 0. & $1 \cdots$ & - & $r$. & FAO \\
\hline MAFF, $1995^{28}$ & - & 0. & - & - & r. & MAFF \\
\hline-- & $\cdot / \cdot \varepsilon$ & $1 / 91$ & .101 & 11/rr & $\cdot / \wedge \mathrm{V}$ & تحقيق حاضر \\
\hline
\end{tabular}

\section{ب.}

اهميت اندازه كيرى غلظت فلزات سنخين در آبزيان بـه دو

مبحث مهم مديريت اكوسيستم و سـامت غـذايى انسـان بـاز

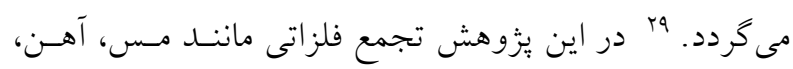
روى، نيكل و سرب در بافت كبد بيش از بافت عضله مشاهده

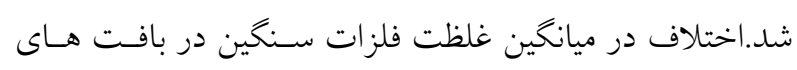
مختلف ماهى توسط محققين زيادى گزارش شده است. الr،r قابليت تجمع يذّيرى در كبد نسبت به عضله براى فلـزات

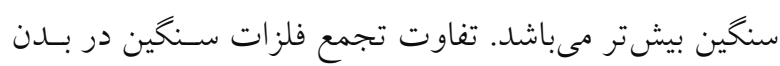

در جدول 0 مقايسه غلظـتهــاى انـدازهخيـرى شـده ايسن تحقيق با حد مجاز استاندارهاى بـين المللسى در بافـت عضـله

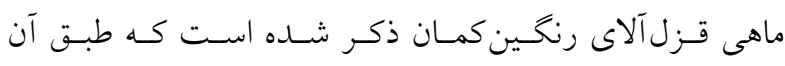
مشخص شد، غلظت فلزات مورد بررسى كمتـر از حســ مجــاز اسـتانداردهاى سـازمان بهراشـت جهـانى مorld Health (Food and Mrganization) Agriculture Organization) و غذاى انخلستان (MAFF) بَ مىباشد. 
ارزيابى غلظت فلزات سنكين و ريسك مصرف آن در ماهى قزلآلاى رنكينكمان (Oncorhynchus mykiss) در حوضجههاى بِرورش ماهى

همكاران (Y.11) در بررسى فلزات مس، آهـن، نيكـل و روى

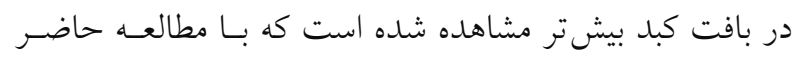
مطابقت دارد. ميانخين غلظت فلز نيكل در بافت كبد و عضد مضدهله

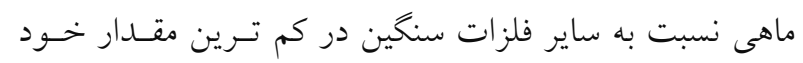

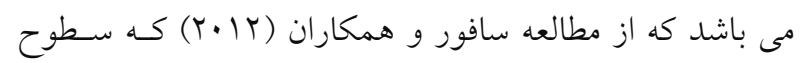

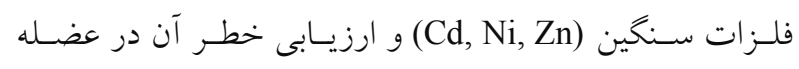

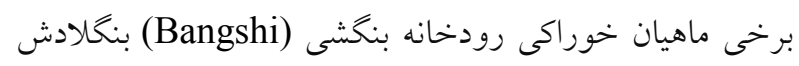

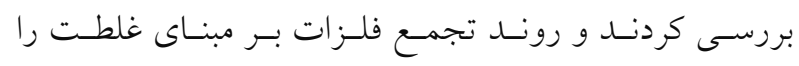

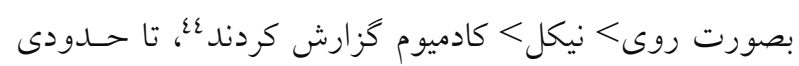

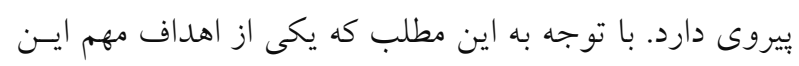

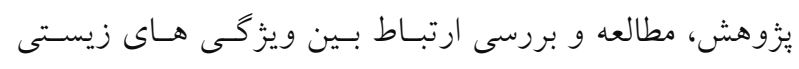

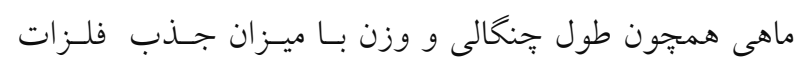

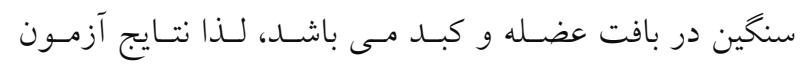

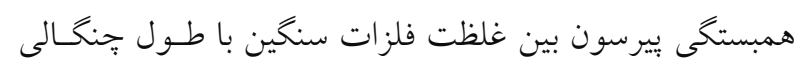

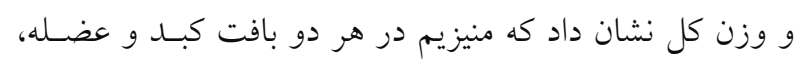

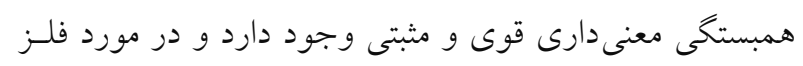

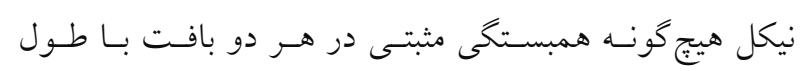

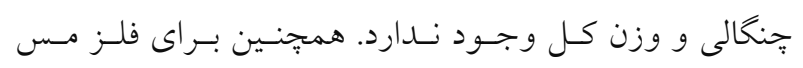

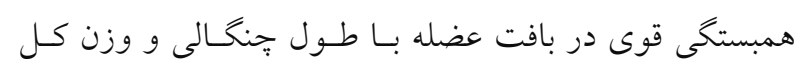

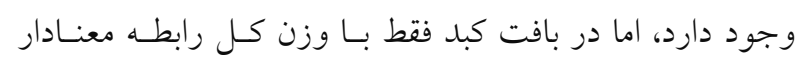

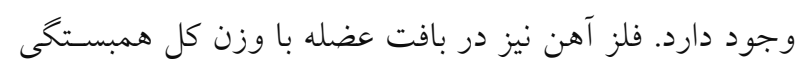

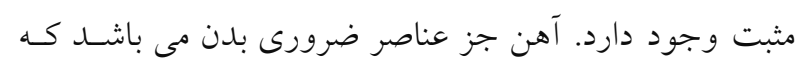

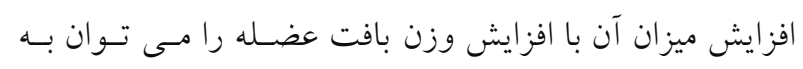

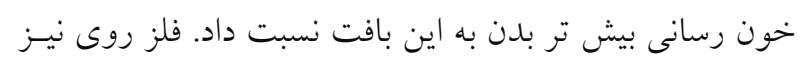

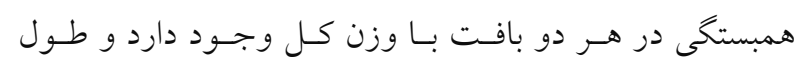

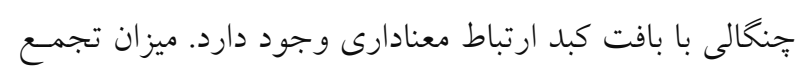

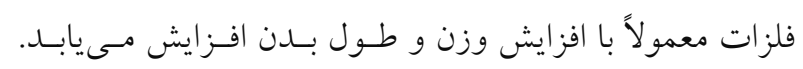

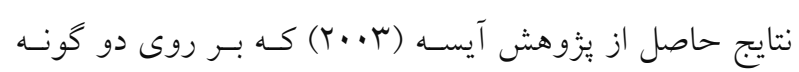
Sparus aurata Mugil cephalus نمود كه بين غلظت فلزات سنخين آهن، مسس، نيكـل، كـروم،

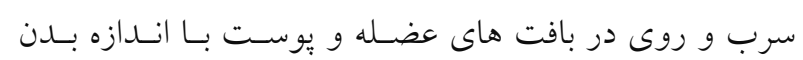

ماهيان با توجه به شرايط اكولوزيكى و زيسـتى و فعاليـتهـاى

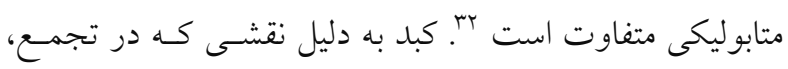

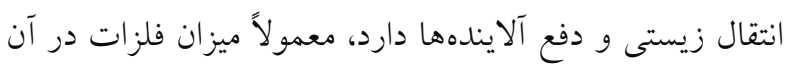

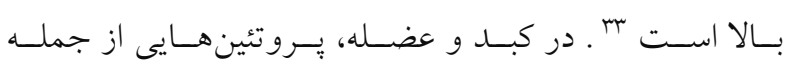
متالوتيونين ها مسئول حذف و خنثى سازى عناصر فلزى و آثـار

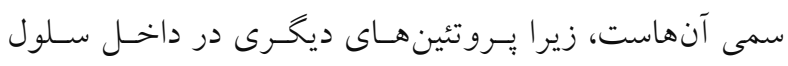

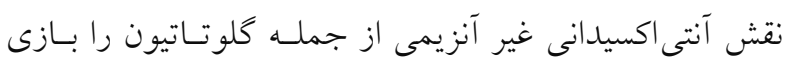

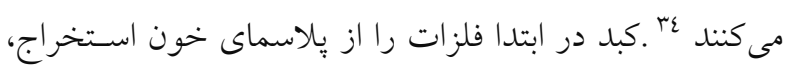

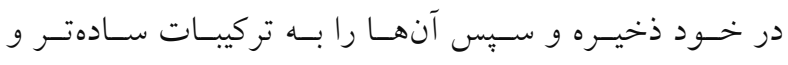

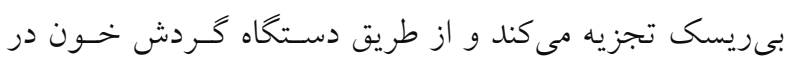

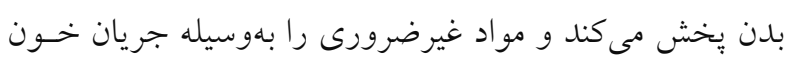

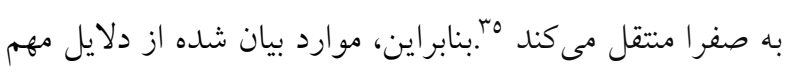
بالا بودن ميزان فلزات مورد مطالعه به جز فلز سـنَّين منيـزيم در بافت كبد نسبت به بافت عضله ماهى قزلآلاى رنخين كمان

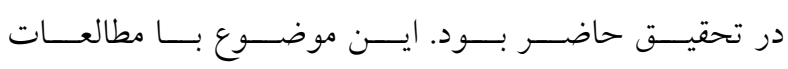
Markabusova

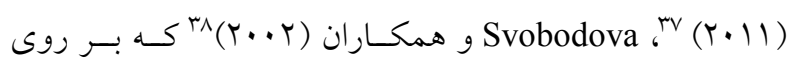

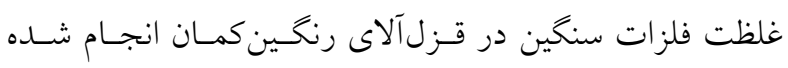

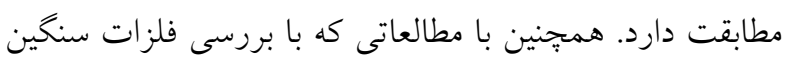

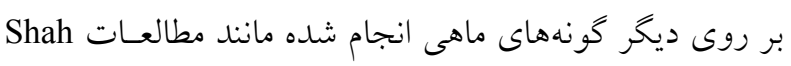

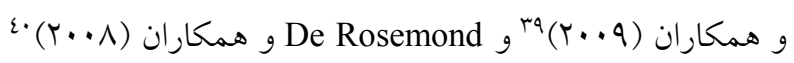
مطابقت دارد. ميزان غلظت فلز ضرورى روى بيش از مس در اين مطالعه

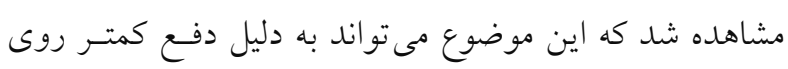

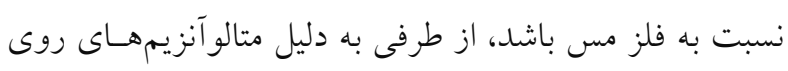

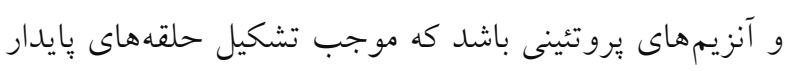

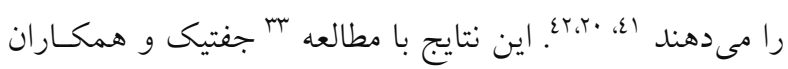

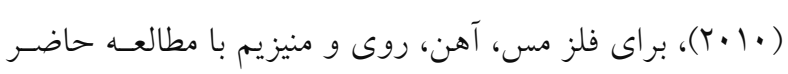

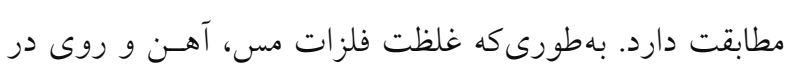

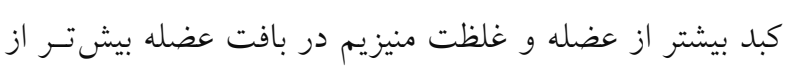

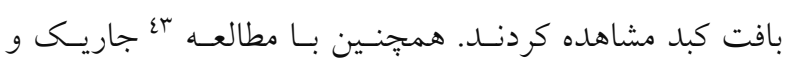




$$
\begin{aligned}
& \text { كنونى مصرف (0r كرم در روز) براى مصـرف كننـد گان آنهـا } \\
& \text { در اين مناطق ريسك هاى آشكارى را بـهـ همـــاه دارد. ميـزان } \\
& \text { شاخص ريسك بيشتــ از يـك بيـانخر ايسن اسـت كـهـ افــراد } \\
& \text { مصرف كننده در اثر مصرف مـاهى قـزلزآلاى رنخـين كمـان در } \\
& \text { معرض ميزان بـيشتـــى از دوز مواجهــهـ قـرار مسى كيرنـــ. در }
\end{aligned}
$$

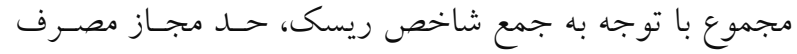

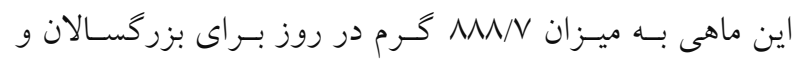

$$
\begin{aligned}
& \text { IVV/V } \\
& \text { ميزان برآورد شاخص ريسك يك ميزان نسبى و محافظه كارانه } \\
& \text { است كه مىتواند تا حدودى امكان وجود ريسك را بــراى مـا } \\
& \text { آشكار كند و بهعنوان يك شاخص مناسب مورد اسـتفاده قـرار } \\
& \text { كيرد317 }
\end{aligned}
$$

\section{Reference}

1. Rana SVS. Environmental pollution (health and toxicology). Alpha Sci Int Limit, Oxford U.K. 2006: 269.

2. Saxena M, Saxena HM, Sangha GK, Kaur K. Effect of heavy metal pollution of water on total plasma proteins and serum protein profiles of Common Carp fish (Cyprinus carpio). J Vet Med 2009; 5(2): unpaginated.

3. Marijic VF, Raspor B. Metal exposure assessment in native fish, Mullus barbatus L., from the Eastern Adriatic Sea. J Toxicol Lett 2007; 168(3): 292-301.

4. Demirezen D, Uruç K. Comparative Study trace elements in certain fish meat and meat products. J Meat Sci 2006; 74(2): 255-60.

5. Aghazadeh MM. Biotoxins present in aquatic animals and their complications. Iran J Vet Soc 2005; 14: 22-35.

6. Moghadasian MH. Advances in dietary enrichment with n-3 fatty acids. J Crit Rev Food Sci Nutr 2008; 48(5): 402-10.

7. Xie $\mathrm{Y}, \mathrm{Chen} \mathrm{Tb}$, Lie M, et al. Spatial distribution of soil heavy metal pollution estimated by different interpolation methods: Accuracy and uncertainty analysis. Chemosphere 2011; 82(3): 468-76.

8. Lashkari Moghaddam NN, Rabbani M, Panahi AE. Investigating the amounts of heavy metals (zinc, cobalt, nickel and cadmium) in canned tuna and its oil. J Mar Sci Technol Res 2008; 3(2): 78-84. [In Persian].

$$
\begin{aligned}
& \text { (طول كـل و وزن بــن ) ارتبـاط مثبـت و معنسى دارى وجـود } \\
& \text { دارده؛. ارتباط بين غلظت فلزات با وزن و طول بدن دلايلى از } \\
& \text { جمله سرعت متابوليسـم و سـرعت رشـــ بافـتهـا همدِنـين }
\end{aligned}
$$

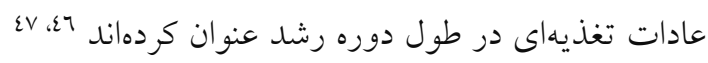$$
\text { تتيجه گيرى }
$$

$$
\begin{aligned}
& \text { در جمع بندى نهايى، با وجود اينكه مقايسه ميـزان غلظـت }
\end{aligned}
$$

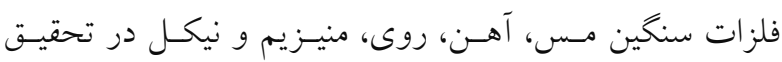

$$
\begin{aligned}
& \text { حاضر با حسـ اسـتاندارد USEPA و و FHO } \\
& \text { غلظت فلزات مذكور كمتر از حد مجاز است. اما نتايج ارزيابى } \\
& \text { شـاخص ريسـى مصـرف ايـن مـاهى را محسدود مسىنمايسـد. } \\
& \text { به طورى كه ميزان برآورد شاخص ريسك براى فلـزات مسس و } \\
& \text { روى بيش از يكى به دست آمد كه مىتوانــ نشـاندهنــده ايسن } \\
& \text { مطلب باشد كه مصرف مـاهى قـزلآلاى موردمطالعـه بـا نـرخ }
\end{aligned}
$$

9. Khayatzadeh J, Abbasi E. The Effects of Heavy Metals on Aquatic Animals. The $1^{\text {st }}$ International Applied Geological Congress; 26-28 April 2010; Department of Geology; Islamic Azad University of Mashad, Iran. [In Persian].

10. FDA (Food and Drug Administration). Dietary reference intakes for vitamin $\mathrm{A}$, vitamin $\mathrm{K}$, arsenic, boron, chromium, copper, iodine, iron, manganese, molybdenum, nickel, silicon, vanadium, and zinc. Report of the Panel on Micronutrients. National Academy Press, Washington DC, Food and Drug Administration. Center for Food Safety and Applied Nutrition; Dietary supplements. 2001.

11. Powers KM, Smith-Weller T, Franklin GM, et al. Parkinson's disease risks associated with dietary iron, manganese, and other nutrient intakes. J Neurol 2003; 60(11):1761-6.

12. Berlin M. Handbook of the Toxicology of Metals. 4th edition. Elsevier, 2014: 1542.

13. Witteman JC, Willett WC, Stampfer MJ, et al. A prospective study of nutrional factors and hypertension among US woman. Circulation 1989; 80(5): 1320-7.

14. Morris RC, Sebastian A. Potanssium responsive hypertension In: Laragh $\mathrm{JH}$, Brenner $\mathrm{BM}$, editors Hypertension. pathophysiology, diagnosis and management. Raven Press, 1995: 311. 


$$
\text { ارزيابى غلظت فلزات سنكين و ريسك مصرف آن در ماهى قزلآلاى رنكينكمان (Oncorhynchus mykiss) در حوضجههاى برورش ماهى }
$$

15. Mazdeh M, Torabian S. Comparison of Serum Levels of Magnesium and Potassium in Stroke Patient and Healthy Controls. J Fasa Univ Med Sci 2011; 1(2): 65-71.

16. Yi Y, Yang Z, Zhang S. Ecological risk assessment of heavy metals in sediment and human health risk assessment of heavy metals in fishes in the middle and lower reaches of the Yangtze River basin. J Environ Pollut 2011; 159(10): 2575-85.

17. USEPA, Guidance for Assessing Chemical Contaminant, Data for Use in Fish Advisories.Risk assessment and fish consumption limits; US Environmental Protection Agency 2000.

18. Yeganeh M. Modeling the process of accumulation of heavy elements in surface soils of Hamedan province and determining the risk of it for human health. Isfahan University of Technology 2012: 250. [dissertation]. [In Persian]

19. Ma J, Singhirunnusorn W. Distribution and Health Risk Assessment of Heavy Metals in Surface Dusts of Maha Sarakham Municipality. J Procedia Soc Behav Sci 2012; 50: 280-93.

20. Mansouri B, Maleki A, Azadi N, et al. Food Risk Assessment of Heavy Metals in Consumption of Common Carp in Zarivar Wetland. J Mazandaran Univ Med Sci 2017; 26(146): 201-5. [Persian]

21. Usero J, Izquierdo C, Morill J, Gracia I. Heavy metals in fish (Solea vulgaris, Anguilla anguilla and liza aurata) from salt marshes on the southern Atlantic coast of Spain. J Environ Int 2004; 29(7): 949-56.

22. Taghavi Jelodar H, Sharifzadeh Baei M, Najafpour Sh, Fazli H. The Comparison of Heavy Metals Concentrations in Different Organs of Liza aurata In habiting in Southern Part of Caspian Sea. J World Appl Sci 2011; 96-100.

23. Ardalan AA, M.Sharif A, Farahani Z. Trace elements accumulation and nutritive value in muscle tissue of golden mullet from the Kiashahr Port (Caspian Sea). J Adv Environ Biol 2012; 6(1): 232-5.

24. Voegborlo RB, Akagi H. Determination of mercury in fish by cold vapor atomic absorption spectrometry using an atomic mercury analyzer. J Food Chem 2007; 100(2): $853-62$.

25. Iranian Fisheries Organization Statistical Yearbook 20012011. Iranian Fisheries Organization Department of Planning and Development Management, the Office of Management and Budget; 2014. [In Persian]

26. WHO (World Health Organization). Health criteria other supporting information. Guidelines for Drinking Water Quality; 1996.

27. FAO (Food and Agriculture Organization). Compilation of legal limits for hazardous substances in fish and fishery products. FAO Fishery Circular. Rome Food and
Agriculture Organization of the United Nations; 2000.

28. MAFF, 1995. Monitoring and surveillance of nonradioactive contaminants in the aquatic environment and activities regulating the disposal of wastes at sea, 1993. Aquatic Environment Monitoring Report. Lowestoft: Direcorate of Fisheries Research; 1993.

29. Dural M, Goksu MZL, Ozak AA. Investigation of heavy metal levels in economically important fish species from the Tuzla lagoon. J Food Chem 2007; 102: 415-21.

30. Canli M, Atli G. The relationship between heavy metal $(\mathrm{Cd}, \mathrm{Cr}, \mathrm{Cu}, \mathrm{Fe}, \mathrm{Pb}, \mathrm{Zn})$ levels and the size of six Mediterranean fish species. J Environ Pollut 2002; 121(1): 129-36.

31. Goyer R. Toxic Effects of Metals In: Amdur MO, Doull JD, Klaassen CD, Eds. Casarett \& Doull's Toxicology, Pergamon Press. 4th Edition. New York, 1991: 623-80.

32. Visnjic-Jeftic Z, Jaric I, Jovanovic L, et al. Heavy metal and trace element accumulation in muscle, liver and gills of the Pontiac shad (Alosa immaculata Bennet 1835) from the Danube River(Serbia), J Microchem 2010; 95(2): 341-9.

33. Rao LM, Padmaja G. Bioaccumulation of heavy metals in M. cyprinoids from the harbor waters of Visakhapatnam. J Bull Pure Appl Sci 2000; 19(2): 77-85.

34. 35. Blázovics A, Abaza M, Sipos $\mathrm{P}$, et al. Biochemical and morphological changes in liverand gallbladder bile of broiler chicken exposed to heavy metals (cadmium, lead, mercury). J Trace Elem Electrolytes 2002; 19(1), 42-7.

35. Harkabusová V, Macharáčková B, Čelechovská O, Vitoulová E. Determination of Arsenic in the Rainbow Trout Muscle and Rice Samples. Czech J Food Sci 2009; 27: 404-6.

36. Svobodova Z, Celechovska O, Machova J, Randak T. Content of arsenic in market-ready rainbow trout (Oncorhynchus mykiss). Acta Vet. Brno 2002; 71: 361-7.

37. Fallah AA, Saei-Dehkordi SS, Nematollahi A, Jafari T. Comparative study of heavy metal and trace element accumulation in edible tissues of farmed and wild rainbow trout (Oncorhynchus mykiss) using ICP-OES technique. Microchemical J 2011; 98: 275-9.

38. Shah AQ, Kazi T, Arain MB, Jamali MK, et al. Accumulation of arsenic in different fresh water fish species - potential contribution to high arsenic intakes. Food Chem 2009; 112: 520-4

39. De Rosemond S, Xie Q, Liber K. Arsenic concentration and speciation in five freshwater fish species from Back Bay near Yellowknife, NT, Canada. Environ Monit and Assess 2008; 147:199-210.

40. 41. Kendrick MH, May MT, Plishka MJ, Robinson KD. Metals in biological systems. England: Ellis Horwood Ltd 1992: 183

41. 42. Schriver DF, Atkins PW, Longford CH. Inorganic 


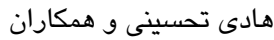

chemistry. Oxford: Oxford University Press. New York, 6th edition. Freeman and Company 2014: 875.

42. Jarić I, Višnjić-Jeftić Z, Cvijanović G, et al. Determination of differential heavy metal and trace element accumulation in liver, gills, intestine and muscle of sterlet (Acipenser ruthenus) from the Danube River in Serbia by ICP-OES. J Microchem 2011; 98(1): 77-81.

43. 44. Rahman MS, Molla AH, Saha N, Rahmanc A. Study on heavy metals levels and its risk assessment in some edible fishes from Bangshi River, Savar, Dhaka, Bangladesh. J Food Chem 2012; 134(4), 1847-54.

44. Yilmaz AB. Comparison of heavy metal level of grey
Mullet (Mugil cephalus L.) and Sea Bream (Sparus aurata L.) caught in Iskenderun Bay. J Environ Sci 2003; 25(2): 115- 48 .

45. Leung PTY, Ip JCH, Mak SST, et al. De novo transcriptome analysis of Perna viridis highlights tissuespecific patterns for environmental studies. J BMC Genomics 2014; 15(1): 1-14.

46. Pourang N, Nikouyan A, Dennis JH. Trace element concentrations in fish, surficial sediments and water from northern part of the Persian Gulf. J Environ Monit Assess 2005; 109(1-3): 293-316. 